\title{
LA TEORIA MONETARIA \\ EN ALFRED MARSHALL
}

FERNANDO MENDEZ IBISATE

Universidad Complutense de Madrid

En una carta de respuesta que Marshall escribió a J. M. Keynes, con motivo del envío por parte de éste de su Tract on Monetary Reform, puede leerse:

«Voy a morir pronto, pero si encuentro oportunidad, preguntaré a los que lleguen a las regiones celestes si han conseguido ustedes encontrar remedio contra los males de la moneda.»

El problema de los desajustes monetarios y del mal funcionamiento del dinero en la economía no es nuevo, ni parece -al menos por el momentoque puede agotarse $\left({ }_{i} \mathrm{He}\right.$ aquí un «mal» abundante, al contrario de los «bienes» de que se ocupa nuestra ciencia!).

$\mathrm{Ni}$ keynesianos ni monetaristas - las dos posturas predominantes hoy día en economía - parecen haber tenido un completo éxito en sus intentos de dar explicación teórica a los problemas de inflación o de crisis y fluctuaciones que se padecen hoy. Ninguna parece capaz de dar con las causas que motivan los movimientos imprevistos de la variable o institución «dinero». Las recetas de política económica que ambas concepciones postulan no parecen tener efectividad a la hora de solucionar o aliviar los desarreglos que padecen el dinero y las demás variables monetarias. Y, desde luego, ninguna de ambas posturas ha dado muestras de gran efectividad a la hora de intentar predecir los movimientos de variables tales como la demanda de dinero, los tipos de interés o el nivel general de precios, por poner algunos ejemplos.

Se plantea, así, un problema monetario que hace del dinero una institución compleja de definir, de entender (su funcionamiento) y de manejar, para los agentes económicos.

Se hace así, pues, necesario una mirada retrospectiva; una vuelta a los «orígenes» construida sobre ese mismo espíritu que llevó a Marshall a decir en una ocasión: «La verdad es la única cosa que vale la pena tener, no la paz.» 
El primer eslabón inmediato anterior, tanto de la teoría monetarista como de la teoría keynesiana, en materia de dinero, destacable, es Alfred Marshall (no podemos estar de acuerdo con Schumpeter, que cita a Walras, pues siendo anterior, el trabajo de Marshall es, al menos, tan bueno como el del autor del equilibrio general).

No sólo es Marshall el continuador de una tradición de pensamiento en cuestiones de dinero y banca que retoma y mejora (con sus nuevas aportaciones) la teoría monetaria postulada por John Stuart Mill y tamizadas por las recomendaciones de W. Bagehot (más con la cabeza que con el corazón). quien cree que debe dejarse el control del dinero en manos de un banco central, único emisor de la moneda y regulador de la política monetaria (en Marshall aparecen ya todos los elementos de un sistema financiero moderno); sino que tanto el keynesianismo como el monetarismo aparecen como un desarrollo lógico de algunas ideas monetarias desarrolladas por Marshall y se inspiran en sus contribuciones. dinero.

Baste aquí señalar un caso: el tratamiento teórico de la demanda de

No por casualidad he elegido el ejemplo. El peculiar estudio que realiza Marshall de la demanda de dinero se debe a su particular enfoque de la teoría «de la cantidad de dinero» de los precios basados en los saldos de caja que los individuos desean mantener.

Comúnmente se atribuye a J. M. Keynes la separación de motivos por los cuales los individuos demandan dinero, en motivos de transacciones, de precaución y de especulación. Es más, los modernos enfoques y estudios de la demanda de dinero han partido de esta separación de motivos, y muchos autores reconocidamente keynesianos han logrado obtener una exposición simple y a la vez rigurosa de cada uno de estos motivos de demanda de dinero, así como de las variables que intervenían en cada caso. Sin embargo, creo haber encontrado indicios suficientes que me permiten afirmar que en Marshall podemos observar perfectamente estudiados los motivos de transacción y precaución de demanda de dinero; y ampliamente esbozado el motivo de especulación, del que Marshall destaca la influencia de variables tales como el tipo de interés y las expectativas en la demanda de saldos reales.

Desde luego, hoy no existe lugar a dudas que Keynes fue -al menos en lo que a materia monetaria se refiere- discípulo de Alfred Marshall; el mismo Keynes admitió esta relación (véase A. C. Pigou, ed., Memorials of Alfred Marsball, Nueva York, A. M. Kelley, 1966, p. 28, nota 2), y el libro de Eprime Eshag From Marshall to Keynes, An Essay on the Monetary Theory of the Cambridge School (1965) lo demuestra con rigor científico.

Con todo ello pretendo subrayar que existe una continuidad (que no supone unanimidad) de pensamiento desatendida de estudio e investigación 
en lo que a cuestiones monetarias se refiere; que el análisis marshalliano en el campo del dinero es muy rico y fundamental para el buen entendimiento de las diversas ramas teóricas que surgen del árbol de la teoría monetaria; y que, pese a todo, no se han dedicado apenas esfuerzos ni trabajos para estudiar la teoría monetaria de Marshall (todos o casi todos los escritos se centran en sus aportaciones a cuestiones del lado real de la economía). Esto supone no hacer justicia a un autor que - como es el caso de Marshalltenía muy presente la importancia y las repercusiones del dinero en el lado real de la economía.

«Voy a morir pronto, pero si encuentro oportunidad, preguntaré a los que lleguen a las regiones celestes si han conseguido ustedes encontrar remedio contra los males de la moneda.»

Si alguno de nosotros pudiera responder hoy a Marshall, no tendría más remedio que aludir al desarrollo de sus idas monetarias, realizado por sus discípulos. La respuesta, aún pareciéndolo, no está muy clara. 